\title{
Proportion of Mesozoic sedimentary rock types: data from northern Eurasia reveal similarities to North American patterns
}

\author{
Dmitry A. Ruban \\ Division of Mineralogy and Petrography, \\ Geology and Geography Faculty, \\ Southern Federal University, Rostov-na-Donu
}

\begin{abstract}
The Mesozoic stratigraphic record of northern Eurasia includes a total of 1,739 formations. The proportion of conglomerate, sandstone + siltstone, shale, carbonates, evaporites, siliceous rocks, and volcanics + volcaniclastics among sedimentary complexes are evaluated for each epoch of the Mesozoic. Sandstone, shale, and conglomerate occur in $86 \%, 71 \%$, and $42 \%$ of formations respectively. Less common are carbonates $(28 \%)$ and volcanics and volcaniclastics $(24 \%)$, whereas evaporites and siliceous rocks are rare $(<5 \%)$. The proportion of particular sedimentary rock types fluctuates throughout the Mesozoic. The proportion of sandstone + siltstone changes quite similarly to that of shale. A comparison of stratigraphic data from northern Eurasia and North America reveals some similarities, including a Lower Triassic increase in the conglomerate proportion, a Middle-Upper Triassic increase in the proportion of siliceous rocks, Upper Triassic-Lower Jurassic and Upper Jurassic-Lower Cretaceous "clastic spikes", and a Middle-Upper Jurassic "carbonate-evaporite spike". They may reflect any global-scale processes. Increases in clastic deposition coincided with eustatic lowstands, whereas voluminous accumulation of carbonates and evaporites tended to coincide with global sea-level rises. It remains unclear whether global climate was responsible for changes in the proportion of sedimentary rock types.
\end{abstract}

Key words: sedimentary rocks, sedimentation, rock proportion, eustasy, climate, Mesozoic, northern Eurasia, North America

\section{Introduction}

The proportion of various types of sediments that accumulated in the Earth's sedimentary basins varied significantly throughout the geologic time. These changes were documented, particularly, by Ronov (1980), Ronov et al. (1980) and

Address: D. A. Ruban: P.O. Box 7333, Rostov-na-Donu, 344056, Russian Federation, e-mails: ruban-d@mail.ru,ruban-d@rambler.ru

Received: February 24, 2010; accepted: October 28, 2010 
Peters (2006). Regional patterns of changes in proportion among some key types of sedimentary rocks reflect both regional and global conditions. The latter can now be evaluated in terms of new plate tectonic reconstructions (Cocks and Torsvik 2002; Stampfli and Borel 2002; Torsvik and Cocks 2004; Scotese 2004; Ruban et al. 2007) and new evaluations of past sea-level changes (Haq et al. 1987; Hallam 1988, 2001; Haq and Al-Qahtani 2005; Miller et al. 2005). Moreover, changes in sedimentation can be used for global modeling (e.g. Ronov et al.1980) and for interregional comparison of sedimentary dynamics.

In this paper, I address the changes in proportion among sedimentary rocks in the Mesozoic based on the data from northern Eurasia. The study area corresponds to the limits of the former USSR, for which excellent lithostratigraphic compilations are available (see below). This territory is comparable to that of North America as studied by Peters (2006) because it embraces a great variety of geologic domains (Fig. 1). Mesozoic sedimentary environments were extremely diverse. Some domains were boreal, whereas others lay close to the Equator; some regions were dominated by continental sedimentation, whereas deep marine basins occupied the others. Finally, this study area represents $\sim 1 / 6$ of the Earth's land surface. The quantitative data reported herein allow a comparison to be made with similar data from North America. Such a comparison helps to identify common patterns and, therefore, to recognize global-scale processes.

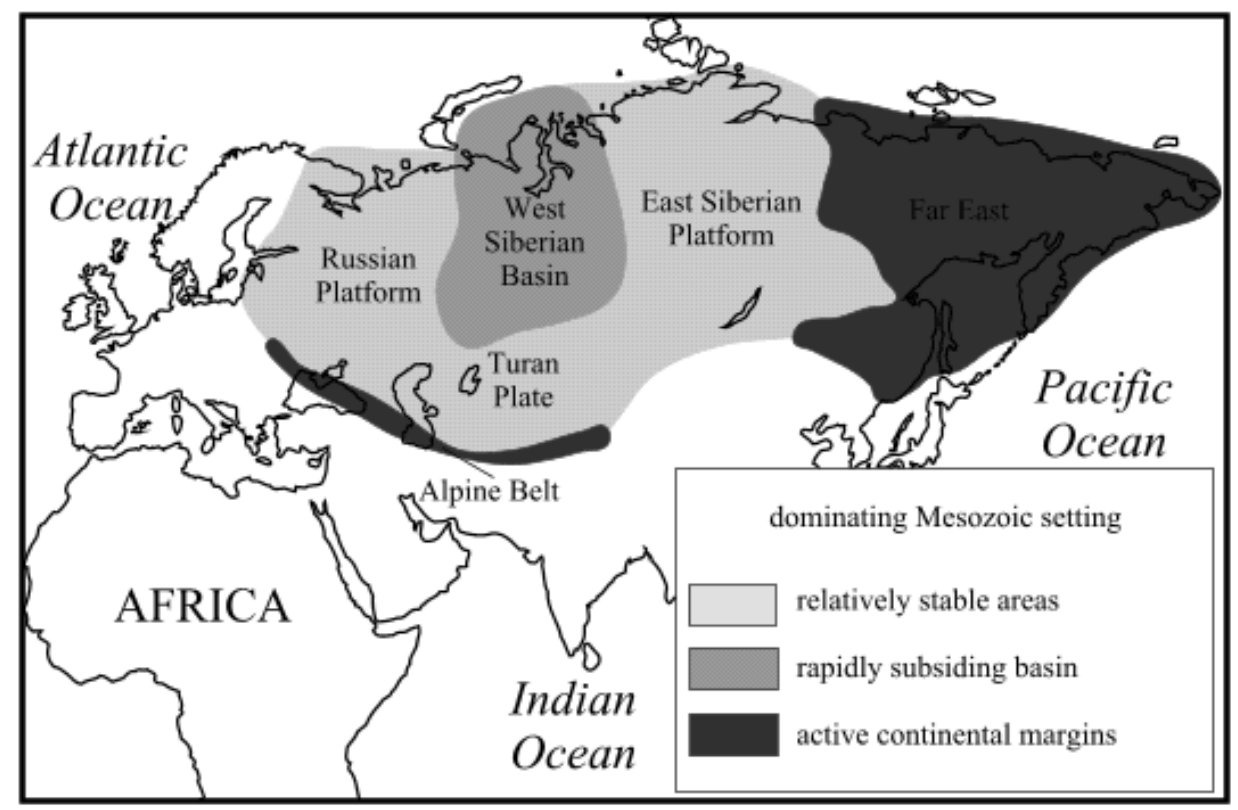

Fig. 1

Location of area considered in this study and schematic representation of its geodynamic setting 


\section{Materials and methods}

The composition and age of the Mesozoic formations established within the territory of northern Eurasia (i.e. ex-USSR) is summarized in a comprehensive synthesis by Prozorovskaya (1979), where 1,739 valid formations and equivalent units are described. Their age is defined as the epoch in which they were deposited. It appears that the quality of this lithostratigraphic knowledge is generally comparable to that of the COSUNA charts (Childs 1985) used by Peters (2006). Despite differences in geologic time resolution (finer in the case of North America), a direct comparison of northern Eurasian and North American units appears possible.

Various techniques have been proposed for the quantitative analysis of sedimentation (Ronov et al. 1980; Hallam and Wignall 1999; Peters and Foote 2001; Smith 2001; Crampton et al. 2003; Peters 2006; Ruban 2006, 2007, 2009). Although Peters (2006) suggested hiatus-bound rock packages as "fundamental units", formations are also useful (e.g. Hallam and Wignall 1999; Ruban 2009). To convert the available lithostratigraphic information on the Mesozoic of northern Eurasia to the data on hiatus-bound packages appears to be difficult because of the presence of intraformational discontinuities and, in places, questionable ages of sedimentary gaps.

For each formation, the presence of the specific type of sedimentary rock was registered. It is suggested that conglomerate, sandstone + siltstone, shale, carbonates, evaporites, siliceous rocks, and volcanics + volcaniclastics be recognized. Volcanics is considered in this paper, because this rock type sometimes plays an important role in sedimentary packages, where it intercalates with other rocks. Peters (2006) recognized evaporites, chert, clastics, mixed carbonate/ clastics, and carbonates, whereas he subdivided clastics into conglomerate, mixed clastics, mudstone/siltstone and sandstone. The present study deals with specific sedimentary rock types, whereas Peters (2006) investigated what he called "lithofacies". The classification of sedimentary rocks preferred herein follows Boggs (2006). However, shale is distinguished from other clastic sediments, whereas siltstone is grouped with sandstone. The reasons are as follows. Conglomerate and sandstone are terrigenous (Boggs 2006), whereas clay can be both detrital and authigenic (Chamley 1989; Weaver 1989; Velde 1992, 1995; Fagel 2007). Siltstone contains less than 30\% clay particles (Boggs 2006) and, consequently, is dominated by terrigenous components. Thus, it needs to be grouped with sandstone rather than with clay. Most of the northern Eurasian formations consist of several types of sedimentary rocks, and some of them (like marlstone) have a composite content. Thus, the number of formations containing each particular sedimentary rock is tallied in the present study accordingly (Table 1). 
Table 1

Distribution of the Mesozoic formations from northern Eurasia by lithology and series. Number of formations is indicated everywhere

\begin{tabular}{|lcccccccc|}
\hline Lithologies & T1 & T2 & T3 & J1 & J2 & J3 & K1 & K2 \\
$\mathrm{Nt}$ & 126 & 77 & 144 & 243 & 293 & 301 & 434 & 406 \\
$\begin{array}{l}\text { total } \\
(1,739) \\
\text { conglomerate }\end{array}$ & 56 & 30 & 77 & 144 & 131 & 124 & 174 & 146 \\
$\begin{array}{l}(732) \\
\text { sandstone and siltstone }\end{array}$ & 108 & 57 & 136 & 234 & 264 & 238 & 384 & 319 \\
$\begin{array}{l}(1,492) \\
\text { shale }\end{array}$ & 92 & 56 & 106 & 191 & 217 & 209 & 304 & 269 \\
$\begin{array}{l}(1,241) \\
\text { carbonates }\end{array}$ & 24 & 17 & 27 & 27 & 43 & 119 & 123 & 155 \\
$\begin{array}{l}(481) \\
\text { evaporites }\end{array}$ & 3 & 0 & 1 & 2 & 3 & 18 & 16 & 21 \\
$\begin{array}{l}(57) \\
\text { siliceous rocks }\end{array}$ & 4 & 3 & 6 & 5 & 7 & 11 & 17 & 27 \\
$\begin{array}{l}(66) \\
\text { volcanics and volcaniclastics } \\
(415)\end{array}$ & 36 & 24 & 27 & 37 & 65 & 73 & 113 & 121 \\
\hline
\end{tabular}

Abbreviation of series: T1 - Lower Triassic, T2 - Middle Triassic, T3 - Upper Triassic, J1 - Lower Jurassic, J2 - Middle Jurassic, J3 - Upper Jurassic, K1 Lower Cretaceous, K2 - Upper Cretaceous. NOTE: some formations contain more than one rock type, and some formations were formed during several epochs.

The proportion of a particular rock type is calculated as follows:

$$
\mathrm{RA}=(\mathrm{Nr} / \mathrm{Nt}) \times 100 \%,
$$

where RA is the relative abundance of the rock in a given series, $\mathrm{Nr}$ is the number of formations containing a given type of rocks within a given epoch, and $\mathrm{Nt}$ is the total number of formations recognized within the study area for a given epoch. The proportion of conglomerate, sandstone + siltstone, shale, carbonates, evaporites, siliceous rocks, and volcanics + volcaniclastics are used to study their relationships in the Mesozoic epochs. In this way we can measure both changes in accumulation of particular sediments and changes in the general character of sedimentation. In both cases, we can (1) delineate the general trends of changes and (2) specify a number of outstanding patterns. It is necessary to emphasize that this paper addresses the proportion (= relative abundance, relative importance) among sedimentary (and volcanic) rocks, and not their absolute mass or accumulation rates.

In order to compare distribution of rock proportion by series and similarity of series, a statistical tool of detrended correspondence analysis (Hill and Gauch 1980 ) is used. Established values of RA (and not those of $\mathrm{Nr}$ ) are counted for this purpose. The paper presents qualitative interpretation of results from this analysis. 


\section{Results}

\section{Northern Eurasian patterns}

A total of 1,739 Mesozoic formations are established within northern Eurasia. The number of formations differs significantly from series to series (Table 1). The Triassic series are characterized by relatively low numbers of formations (126 for the Lower Triassic, 77 for the Middle Triassic, and 144 for the Upper Triassic). Jurassic series are represented by a larger number of formations (243 Lower Jurassic, 293 Middle Jurassic, and 301 Upper Jurassic). The number of formations in the Cretaceous is larger still: there are 434 units of Lower Cretaceous and 406 units of Upper Cretaceous. Thus, the Mesozoic of northern Eurasia shows a stepwise increase in formation numbers. It appears that sedimentation during the Mesozoic was dominated by sand, clay, and conglomerate. The equivalent rocks are known in $1492(\mathrm{RA}=86 \%), 1241(\mathrm{RA}=71 \%)$, and $732(\mathrm{RA}=42 \%)$ formations, respectively. Carbonates and volcanics + volcaniclastics were much less abundant. They are contained in $481(\mathrm{RA}=28 \%)$ and $415(\mathrm{RA}=24 \%)$ formations respectively. The least abundant were siliceous (66 formations, $\mathrm{RA}=4 \%$ ) and evaporite (57 formations, $\mathrm{RA}=3 \%$ ) rocks. Thus, clastic sedimentation prevailed during the Mesozoic in northern Eurasia.

The proportion of the main sedimentary rock types changes in a different fashion (Table 2, Fig. 2). The proportion of conglomerates does not fluctuate much in the Mesozoic (Fig. 2). Its maximum is reached in the Upper Triassic-Lower Jurassic, whereas the lowest values of RA for conglomerate are registered for the Middle Triassic and the Upper Cretaceous. A general trend of decreasing relative abundance of conglomerate begins in the Middle Jurassic and continues to the end of the Mesozoic. The proportion of sandstone and siltstone was also rather stable within the time span considered (Fig. 2), but no trend is evident. Three sharp increases in sand deposition, however, are noted. They occurred in the Early Triassic, the Late Triassic-Middle Jurassic, and the Early Cretaceous. The proportion of shale increases since the Lower Triassic (Fig. 2). After a peak in the

\section{Table 2}

Proportion of the main rock types (RA, \%) among the other sedimentary rocks in the Mesozoic of northern Eurasia. See Table 1 for abbreviation of series

\begin{tabular}{|lcccccccc|}
\hline Lithologies & T1 & T2 & T3 & J1 & J2 & J3 & K1 & K2 \\
Conglomerate & 44 & 39 & 53 & 59 & 45 & 41 & 40 & 36 \\
Sandstone and siltstone & 86 & 74 & 94 & 96 & 90 & 79 & 88 & 79 \\
Shales & 73 & 73 & 74 & 79 & 74 & 69 & 70 & 66 \\
Carbonates & 19 & 22 & 19 & 11 & 15 & 40 & 28 & 38 \\
Evaporites & 2 & 0 & 1 & 1 & 1 & 6 & 4 & 5 \\
Siliceous rocks & 3 & 4 & 4 & 2 & 2 & 4 & 4 & 7 \\
Volcanics and volcaniclastics & 29 & 31 & 19 & 15 & 22 & 24 & 26 & 30 \\
\hline
\end{tabular}

NOTE: some formations contain more than one rock type, and some formations were formed during several epochs 

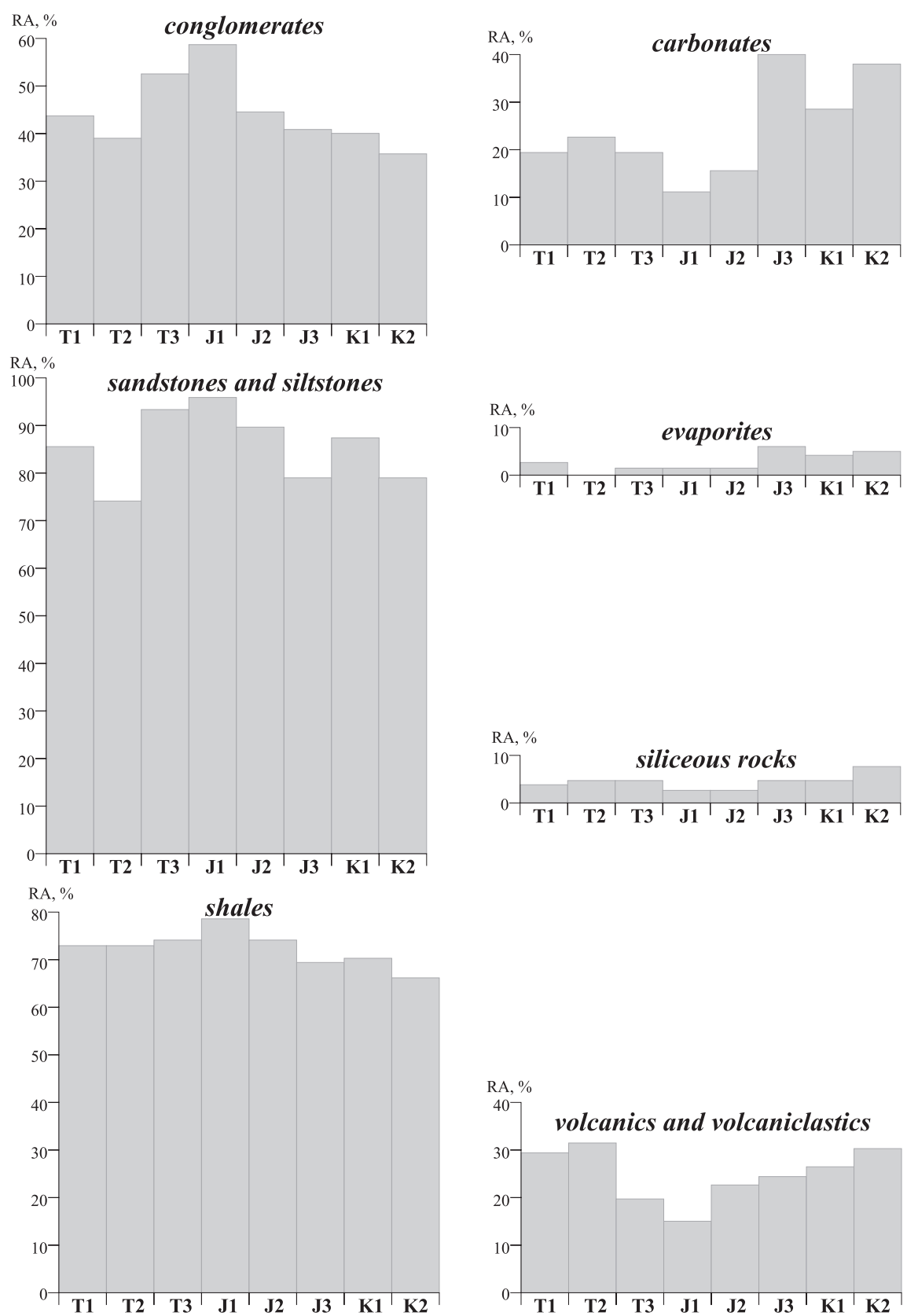

Fig. 2

Proportion of particular rock types (RA) among the other sedimentary rocks in the Mesozoic of northern Eurasia. Data are taken from Table 2. See Table 1 for abbreviation of series 
Lower Jurassic, it decreases toward the Upper Cretaceous. In contrast, the proportion of carbonates fluctuates noticeably (Fig. 2). A general increase in relative abundance of carbonate is interrupted by two prominent drops, which took place in the Upper Triassic-Lower Jurassic and the Lower Cretaceous. Evaporites were abundant only in the Upper Jurassic-Lower Cretaceous (Fig. 2). No evaporites are reported from the Middle Triassic formations. Siliceous sediments are of low abundance during the entire Mesozoic, although they increase slightly in the Upper Cretaceous (Fig. 2). The relative abundance of volcanics and volcaniclastics remains high in the Lower-Middle Triassic, then decreases significantly, and rises again in the Middle Jurassic-Upper Cretaceous (Fig. 2).

The documented proportion of sedimentary rocks (Fig. 2) allows judging about Mesozoic depositional processes in northern Eurasia. The Early-Middle Triassic sedimentation in northern Eurasia was dominated by sand, silt, and clay. In the Late Triassic the importance of volcanics and volcaniclastics decreased, whereas that of conglomerate increased. Thus, sedimentation was dominated again by clastics and shale. In the Lower Jurassic, the proportion of clastics becomes extremely large. In the Middle Jurassic the proportion among sedimentary rocks remains the same, although the importance of carbonates and volcanics + volcaniclastics increases. Clastic sedimentation dominated northern Eurasia until the end of the Mesozoic, though its significance decreased gradually. Simultaneously the role of deposition of carbonates and volcanics + volcaniclastics rose, with maxima in the Late Jurassic and the Late Cretaceous, respectively. The Upper Jurassic was the oldest Mesozoic series in which the relative abundance of carbonates ( $40 \%$ of formations) is comparable with that of conglomerate ( $41 \%$ of formations). However, neither carbonates nor conglomerates reach the relative abundance of sandstone and siltstone or shale. In the Early-Late Cretaceous northern Eurasia was dominated by the accumulation of sand and silt.

There are three outstanding patterns outlined by the measured sedimentary rock proportion. The first pattern I call the "clastic spike", which is a significant increase in the proportion of conglomerate, sandstone, and siltstone in the Upper Triassic-Lower Jurassic (Fig. 2). The second pattern, the "carbonate-evaporite spike", is reflected in a dramatic increase in the importance of carbonate and evaporite deposition in the Late Jurassic (Fig. 2). The third pattern, the "sandstone spike", is a short-term increase in the proportion of sandstone and siltstone in the Lower Cretaceous (Fig. 2). It is possible to identify an additional pattern named the "volcanic demise". It occurs in the Lower Jurassic, when the proportion of formations containing volcanics and volcaniclastics dropped to its minimum (Fig. 2).

Results of the detrended correspondence analysis (Fig. 3) suggest that the Mesozoic dynamics of proportion of the main sedimentary rock types differed significantly with only one exception. The relative abundance of sandstone + 


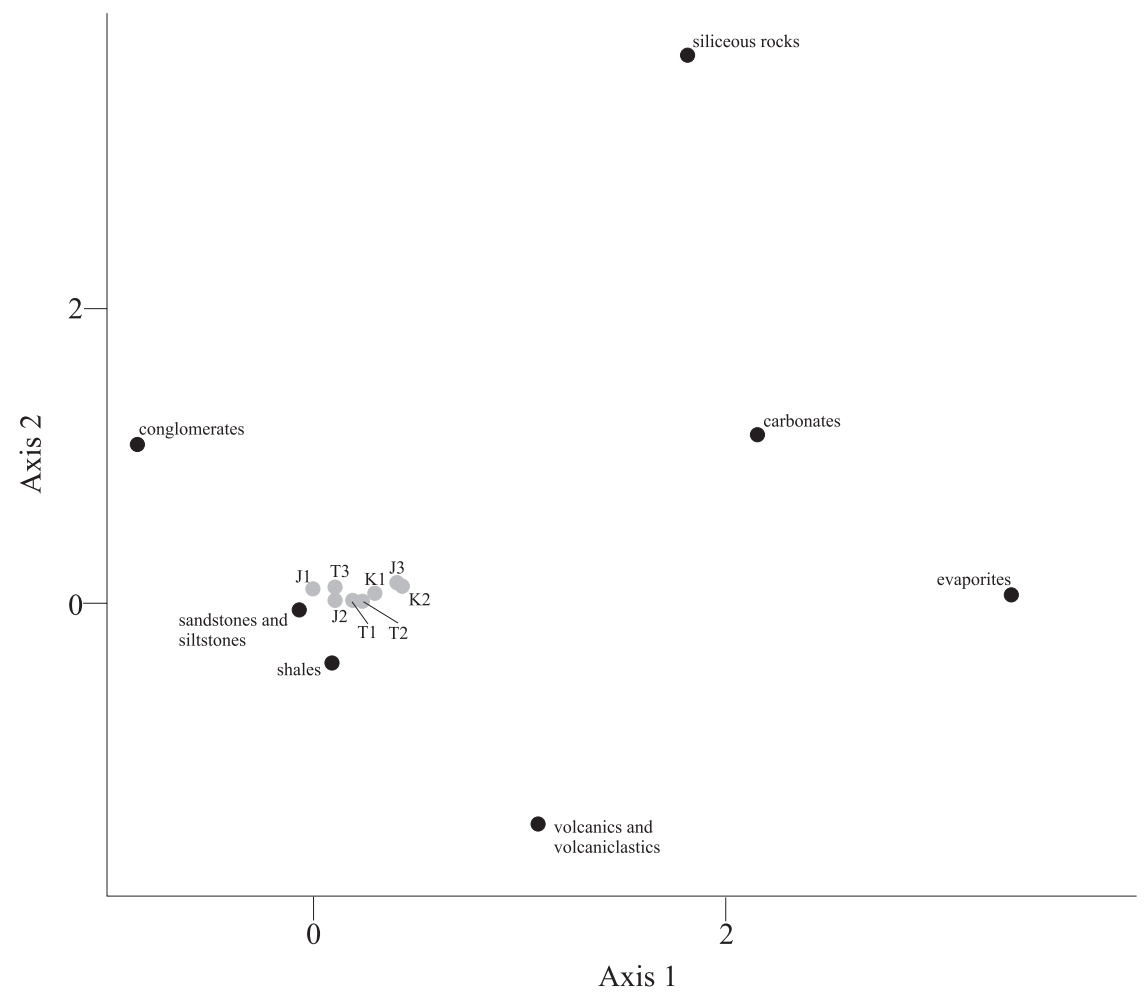

Fig. 3

Results of the detrended correspondence analysis of the relative abundance of rock types (RA) in the Mesozoic series. Data are taken from Table 2. Distance between dots is significant for judging about similarity and clusters (see http://ordination.okstate.edu/DCA.htm for more explanations of this statistical tool). See Table 1 for abbreviation of series

siltstone and shale changes similarly. This allows one to suggest a deposition of these rock types by the same processes and, thus, a relatively low differentiation of medium-to-fine clastics by grain size in the course of depositional processes. As for the Mesozoic series, they were quite similar by representation of sedimentary rock types (Fig. 3). The most dissimilar were the Lower Jurassic and the Upper Cretaceous. However, it is impossible to reach a conclusion about any definite trend of changes because the Upper Triassic is grouped closely to the Middle Jurassic and the Late Jurassic is grouped closely to the Upper Cretaceous.

\section{Comparison with North America}

In North America, Mesozoic sedimentation was dominated by clastics (Peters 2006). The same is true for northern Eurasia, as shown above. The calculations made by Peters (2006) suggest that fluctuations in the proportion of particular 
sedimentary rocks were large, with no evident trends (Fig. 4). This is also the case for northern Eurasia. However, specific patterns can be compared and allow us to draw some important conclusions.

Three patterns, marked by an increase in the proportion of conglomerate in North America, occur in the Early-Middle Triassic, the Early Jurassic, and the Early Cretaceous (Peters 2006). The first two of them can be recognized in northern Eurasia (Fig. 2). The proportion of total clastics (i.e. conglomerate, sand, siltstone and clay) increases dramatically at the Triassic-Jurassic and JurassicCretaceous transitions in North America (Fig. 4). These correspond to the "clastic spike" and the "sandstone spike", respectively, which were noted in northern Eurasia (see above). Four episodes of an increase in carbonate deposition are established in North America (Fig. 4). They occurred in the Early Triassic, the Middle Triassic, the Middle Jurassic, and the late Early Cretaceous. The first and the last ones are not found in northern Eurasia (Fig. 2). However, the Middle Triassic pattern, although less significant, is also registered in northern Eurasia, and the Middle Jurassic pattern in North America corresponds with the above-mentioned "carbonate-evaporite spike", although with some delay. As for evaporites, a prominent peak in their relative abundance is registered in North America in the Middle-Upper

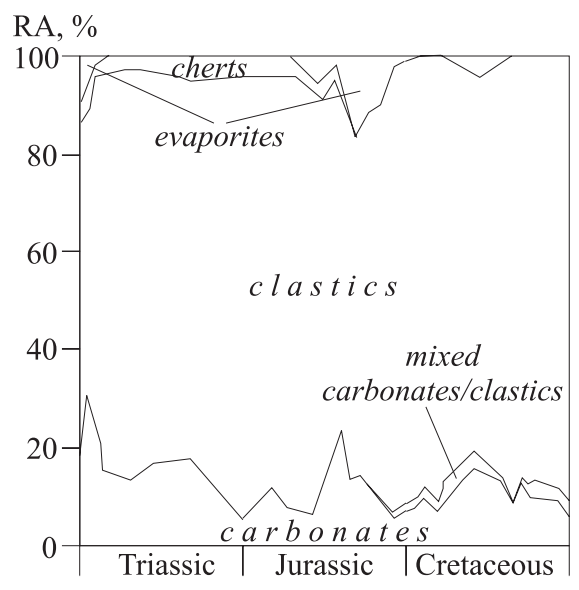

Fig. 4

Sedimentary rock proportion in the Mesozoic of North America (modified after Peters 2006) Jurassic (Fig. 4) and corresponds well with the northern Eurasian "carbonate-evaporite spike" (Fig. 2). Another smaller evaporite peak, evident in the upper Lower Cretaceous of North America (Fig. 4) is not recognized in northern Eurasia, although evaporite deposition was relatively voluminous during this epoch (Fig. 2). Siliceous rocks of Triassic-Early Jurassic ages are relatively abundant in North America (Fig. 4). In northern Eurasia, the Middle-Late Triassic is characterized by a slightly larger proportion of siliceous rocks (Fig. 2).

The comparison of Mesozoic sedimentary records between North America and northern Eurasia permits the delineation of several similar patterns. These are a Lower Triassic increase in the conglomerate proportion, a Middle-Upper Triassic increase in the proportion of siliceous rocks, Upper Triassic-Lower Jurassic and Upper Jurassic-Lower Cretaceous "clastic spikes", and a Middle-Upper Jurassic "carbonate-evaporite spike". It would be meaningful to search for them in the famous reconstructions by Ronov et al. (1980), but the latter deals with mixed 
lithologies. Thus, data from Ronov et al. (1980) is not detailed enough to discuss the above-mentioned common patterns. An exception is the increase in carbonate proportion in the Upper Jurassic, which is documented by Ronov et al. (1980). Additionally, the recently published compilation by Hay et al. (2006) reveals a remarkable episode of halite deposition that embraced the Late Jurassic and the Early Cretaceous and, therefore, matches our "carbonate-evaporite spike".

\section{Discussion}

\section{Changes in total formation number}

The more-or-less stepwise increase in the number of formations per series in northern Eurasia throughout the Mesozoic may reflect three different factors (Fig. 5). First, an increase in the number of formations may indicate a diversity of sedimentary environments. The more sedimentary environments there are, the more likely it is that there will be more lithostratigraphic units recognized. This is partly supported by our results. An increase in proportion of carbonates, evaporites, and volcanics + volcaniclastics in the second half of the Mesozoic (Fig. 2) may indicate a diversification of depositional environments. The second

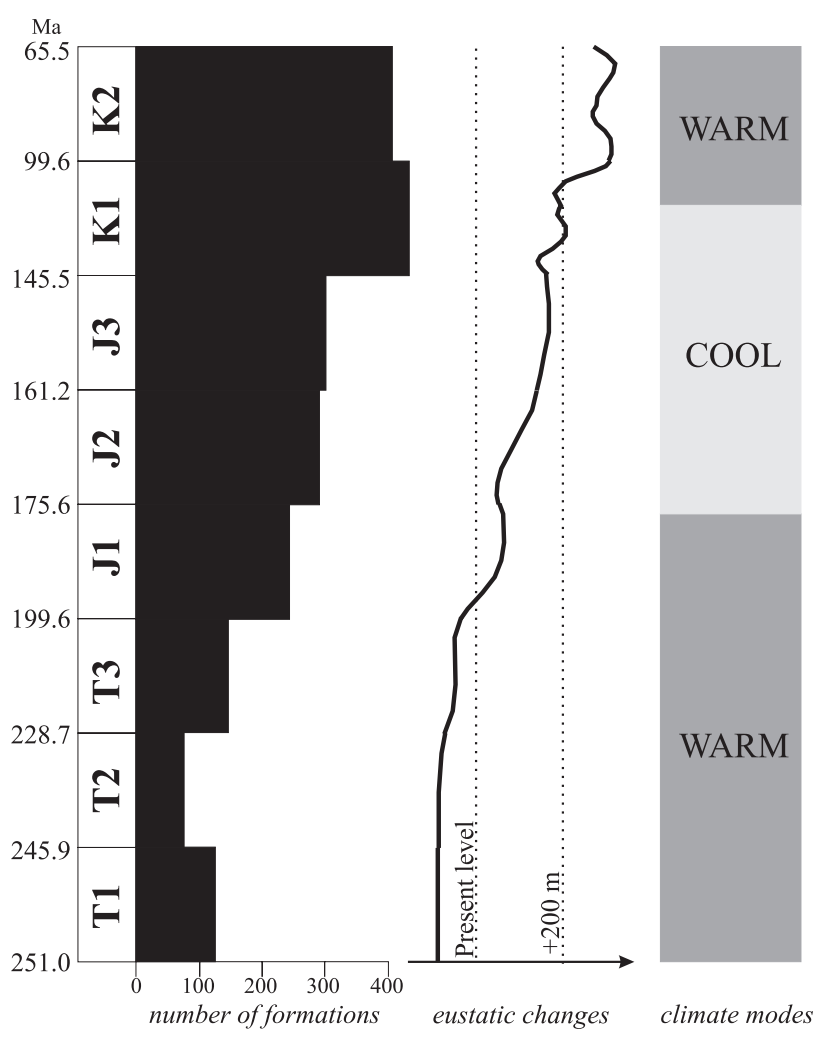

Fig. 5

Number of formations in northern Eurasia, eustatic changes (re-scaled from Haq and Al-Qahtani 2005), and climate modes (after Frakes et al. 1992; Gröcke 2009) Numeric ages are those recommended by the International Commission on Stratigraphy (Ogg et al. 2008; see also www.stratigraphy. org). See Table 1 for abbreviation of series 
factor is the sediment preservation potential. The eustatic sea-level rise during the Mesozoic (Haq and Al-Qahtani 2005) (Fig. 5) might have protected deposits from further erosion. Note that even non-marine sedimentation can be affected by sea-level changes (Catuneanu 2006). The third factor has to do with the absolute lengths of the Mesozoic epochs (Ogg et al. 2008). In general, the longer the epoch the larger is the number of formations, but there are exceptions. The Early Jurassic, for instance, was longer than the Middle Jurassic, but the number of Lower Jurassic formations is lower. Similarly, the Middle Triassic was much longer than the Early Triassic, but the number of Lower Triassic formations is larger.

\section{Global paleoenvironmental controls on sedimentary rock proportion}

Those Mesozoic patterns recorded by the changes in the proportion of sedimentary rocks common to both northern Eurasia and North America, should have global-scale explanations. The continents being compared had distinct tectonic settings during most of the Mesozoic and they were not linked tectonically (Stampfli and Borel 2002; Scotese 2004). In other words, these common patterns undoubtedly reflect specific global conditions. Among numerous possible explanations for the documented patterns, I emphasize eustatic fluctuations and climate.

The Mesozoic eustatic fluctuations are reconstructed by Haq et al. (1987) and were recently re-evaluated by Haq and Al-Qahtani (2005) (Fig. 5). The high proportion of Lower Triassic conglomerate evidently corresponds to the extremely low global sea level. There were no major changes in the global sea level at the Triassic-Jurassic transition, and it is therefore impossible to establish eustatic causes for the Late Triassic-Early Jurassic "clastic spike". However, Hallam and Wignall (1999) and Hallam (2001) suggested a prominent regression at the Triassic-Jurassic transition, which was caused by mantle plume activity. Some drop in global sea level at the beginning of the Cretaceous may explain another "clastic spike", which occurred in the Late Jurassic-Early Cretaceous. As for the Middle-Late Triassic increase in the proportion of siliceous rocks and the MiddleLate Jurassic "carbonate-evaporite spike", both took place during a long-term gradual eustatic sea-level rise.

It is not evident whether the global climate (Fig. 5) might have been linked with the reported patterns common for northern Eurasia and North America. The increases in clastic deposition occurred during both warm and cool climate regimes. Although carbonates and evaporites became abundant together with establishing of the cool mode in the Middle Jurassic, their deposition was also significant in the Late Cretaceous, when the climate was warm. Much, however, depends on how we reconstruct the Mesozoic climates. The modes established by Frakes et al. (1992) and Gröcke (2009) do not coincide with some recent suggestions, e.g. those on minor glaciations during the Late Cretaceous (Galeotti et al. 2009). 


\section{Conclusions}

The study of proportion among Mesozoic sedimentary rocks within northern Eurasia leads to the three following conclusions:

1) the Mesozoic sedimentary complexes of northern Eurasia are dominated by sandstone, siltstone, and shale;

2) similar patterns are recognized in northern Eurasia and North America, which include a Lower Triassic increase in the conglomerate proportion, a Middle-Upper Triassic increase in the proportion of siliceous rocks, Upper Triassic-Lower Jurassic and Upper Jurassic-Lower Cretaceous "clastic spikes", and a Middle-Upper Jurassic "carbonate-evaporite spike";

3) eustatic changes might have been an important global control on proportions of sedimentary rocks during the Mesozoic.

Further studies are needed in order to document the proportion of sedimentary rock types on other continents, like South America, Africa, and Australia.

\section{Acknowledgements}

The author gratefully thanks G. Császár (Hungary) and J. Pálfy (Hungary) for their important suggestions, G. Schmiedl (Hungary) for his editorial support, and $\mathrm{N}$. W. Jones (USA) for his valuable improvements of the preliminary version of this paper. The help with literature by F. Berra (Italy), N. M. M. Janssen (Netherlands), W. Riegraf (Germany), and A. Schoonmaker (USA) is highly appreciated.

\section{References}

Boggs, S., Jr. 2006: Principles of Sedimentology and Stratigraphy. - Upper Sadler River, Pearson Prentice Hall, 662 p.

Catuneanu, O. 2006: Principles of Sequence Stratigraphy. - Amsterdam, Elsevier. 375 p.

Chamley, H. 1989: Clay Sedimentology. - Berlin, Springer. 623 p.

Childs, O.E. 1985: Correlation of stratigraphic units of North America: COSUNA. - American Association of Petroleum Geologists, Bulletin, 69, pp. 173-180.

Cocks, L.R.M., T.H. Torsvik 2002: Earth geography from 500 to 400 million years ago: a faunal and palaeomagnetic view. - Journal of the Geological Society, London, 159, pp. 631-644.

Crampton, J.S., A.G. Beu, R.A. Cooper, C.M. Jones, B. Marshall, P.A. Maxwell 2003: Estimating the rock volume bias in paleobiodiversity studies. - Science, 301, pp. 358-360.

Fagel, N. 2007: Clay Minerals, Deep Circulation and Climate. - In: Hillaire-Marcel, C., A. de Vernal (Eds): Proxies in Late Cenozoic paleoceanography. Amsterdam, Elsevier, pp. 139-184.

Frakes, L.A., J.E. Francis, J.I. Syktus 1992: Climate modes of the Phanerozoic: The history of the Earth's climate over the past 600 million years. - Cambridge University Press, Cambridge. $286 \mathrm{p}$.

Galeotti, S., G. Rusciadelli, M. Sprovieri, L. Lanci, A. Gaudio, S. Pekar 2009: Sea-level control on facies architecture in the Cenomanian-Coniacian Apulian margin (Western Tethys): A record of glacio-eustatic fluctuations during the Cretaceous greenhouse? - Palaeogeography, Palaeoclimatology, Palaeoecology, 276, pp. 196-205. 
Gröcke, D. 2009: "Greenhouse" (warm) climates. - In: Gornitz, V. (Ed.): Encyclopedia of Paleoclimatology and Ancient Environments. Springer, Dordrecht, pp. 397-405.

Hallam, A. 1988: A re-evaluation of Jurassic eustasy in the light of new data and the revised Exxon curve. - In: Wilgus, C.K., B.S. Hastings, C.G.St.C. Kendall, H.W. Posamentier, C.A. Ross, J.C. Van Wagoner (Eds): Sea-Level Changes - An Integrated Approach. Society for Economic Paleontologists and Mineralogists Special Publication, 42, pp. 261-273.

Hallam, A. 2001: A review of the broad pattern of Jurassic sea-level changes and their possible causes in the light of current knowledge. - Palaeogeography, Palaeoclimatology, Palaeoecology, 167 , pp. 23-37.

Hallam, A., P.B. Wignall 1999: Mass extinctions and sea-level changes. - Earth-Science Reviews, 48, pp. 217-250.

Haq, B.U., A.M. Al-Qahtani 2005: Phanerozoic cycles of sea-level change on the Arabian Platform. GeoArabia, 10, pp. 127-160.

Haq, B.U., J. Hardenbol, P.R. Vail 1987: Chronology of Fluctuating Sea Levels Since the Triassic. Science, 235, pp. 1156-1167.

Hay, W.W., A. Migdisov, A.N. Balukhovsky, Ch.N. Wold, S. Flögel, E. Söding 2006: Evaporites and the salinity of the ocean during the Phanerozoic: Implications for climate, ocean circulation and life. - Palaeogeography, Palaeoclimatology, Palaeoecology, 240, pp. 3-46.

Hill, M.O., H.G. Gauch, Jr. 1980: Detrended Correspondence Analysis: an improved ordination technique. - Vegetation, 42 , pp. 47-58.

Miller, K.G., M.A. Kominz, J.V. Browning, J.D. Wright, G.S. Mountain, M.E. Katz, P.J. Sugarman, B.S. Cramer, N. Christie-Blick, S.F. Pekar 2005: The Phanerozoic Record of Global Sea-Level Change. - Science, 310, pp. 1293-1298.

Ogg, J.G., G. Ogg, FM. Gradstein 2008: The Concise Geologic Time Scale. - Cambridge, Cambridge University Press. $177 \mathrm{p}$

Peters, S.E. 2006: Macrostratigraphy of North America. - Journal of Geology, 114, pp. 391-412.

Peters, S.E., M. Foote 2001: Biodiversity in the Phanerozoic: a reinterpretation. - Paleobiology, 27, pp. 583-601.

Prozorovskaya, E.L. (Ed.) 1979: Stratigrafitcheskij slovar' SSSR. Trias, jura, mel [Stratigraphic references of the USSR. Triassic, Jurassic, Cretaceous]. - Nedra, Leningrad. 592 p. (In Russian.)

Ronov, A.B. 1980: Osadotchnaja obolotchka Zemli [The sedimentary shell of the Earth]. - Nauka, Moskva. 80 p. (In Russian.)

Ronov, A.B., V.E. Khain, A.N. Balukhovsky, K.B. Seslavinsky 1980: Quantitative analysis of Phanerozoic sedimentation. - Sedimentary Geology, 25, pp. 311-325.

Ruban, D.A. 2006: Taxonomic diversity dynamics of the Jurassic bivalves in the Caucasus: Regional trends and recognition of global patterns. - Palaeogeography, Palaeoclimatology, Palaeoecology, 239, pp. 63-74.

Ruban, D.A. 2007: Jurassic transgressions and regressions in the Caucasus (northern Neotethys Ocean) and their influences on the marine biodiversity. - Palaeogeography, Palaeoclimatology, Palaeoecology, 251, pp. 422-436.

Ruban, D.A. 2009: Distribution of sedimentary rock types through time in a back-arc basin: A case study from the Jurassic of the Greater Caucasus (Northern Neotethys). - Central European Geology, 52, pp. 73-96.

Ruban, D.A., M.I. Al-Husseini, Y. Iwasaki 2007: Review of Middle East Paleozoic plate tectonics. GeoArabia, 12, pp. 35-56.

Scotese, C.R. 2004: A continental drift flipbook. - Journal of Geology, 112, pp. 729-741.

Smith, A.B. 2001: Large-scale heterogeneity of the fossil record: implications for Phanerozoic biodiversity studies. - Philosophical Transactions of the Royal Society of London B, 356, pp. 351-367.

Stampfli, G.M., G.D. Borel 2002: A plate tectonic model for the Paleozoic and Mesozoic constrained by dynamic plate boundaries and restored synthetic oceanic isochrons. - Earth and Planetary Science Letters, 196, pp. 17-33. 
Torsvik, T.H., L.R.M. Cocks 2004: Earth geography from 400 to 250 Ma: a palaeomagnetic, faunal and facies review. - Journal of the Geological Society, London, 161, pp. 555-572.

Velde, B. 1992: Introduction to clay minerals. - London, Chapman and Hall. 198 p.

Velde, B. 1995: Origin and mineralogy of clays. Clays and the environment. - Berlin, Springer. 356 p. Weaver, C.E. 1989: Clays, muds, and shales. - Amsterdam, Elsevier. 819 p. 